\title{
What Makes Access Services Staff Happy? A Job Satisfaction Survey
}

\section{Charla Gilbert}

Director of Assessment and

Library Access Services

Virginia Tech

560 Drillfield Drive

Blacksburg, VA 24061

charla70@vt.edu

Phone: 540-231-9406

\section{Bethany Sewell}

Access Services and

Reference Librarian The College of New Jersey 2000 Pennington Road Ewing, NJ 08628-0718 sewellb@tcnj.edu

Phone: 609-771-2405 


\section{About the Survey}
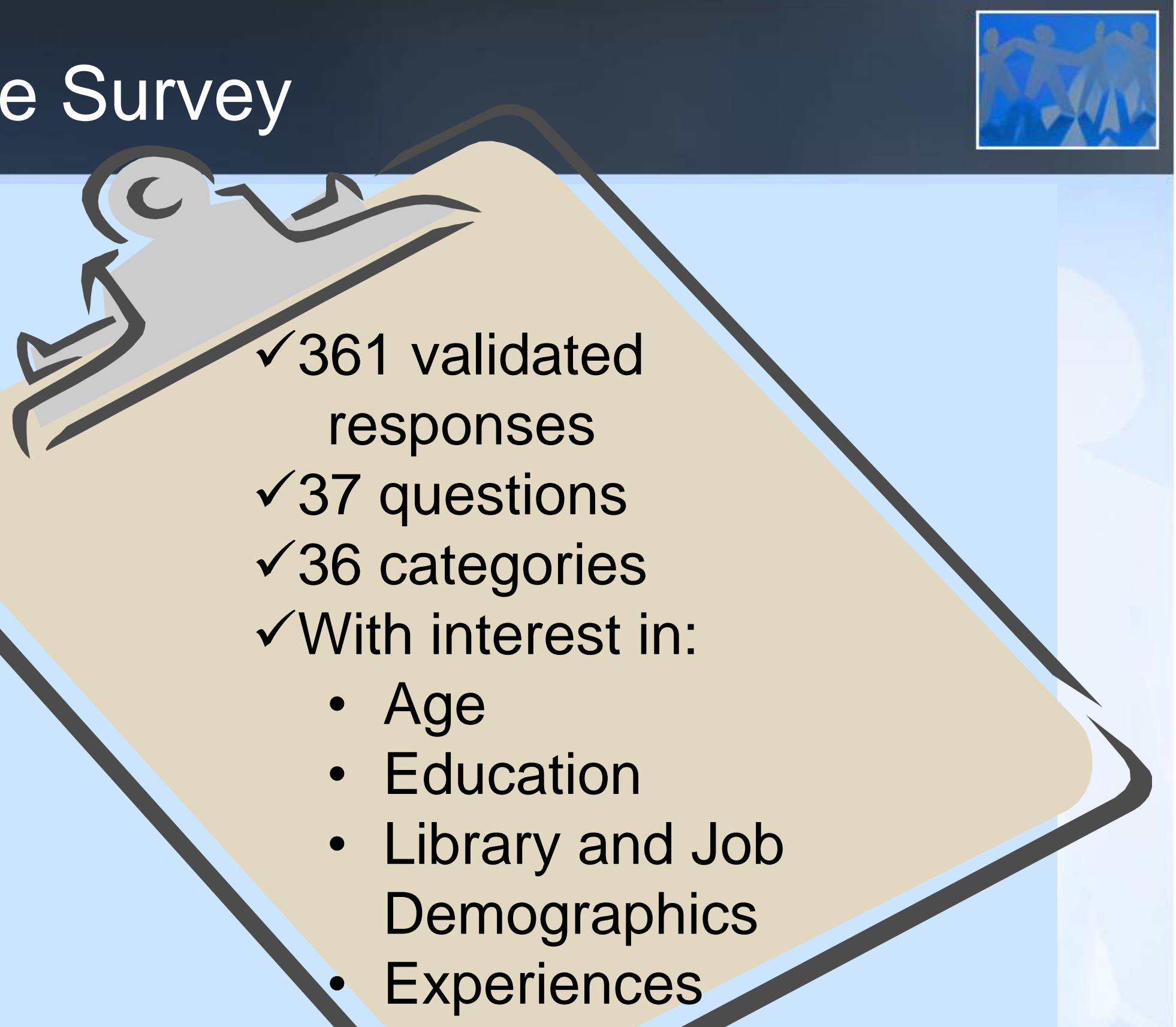


\section{Access Services are Complex and Dynamic}
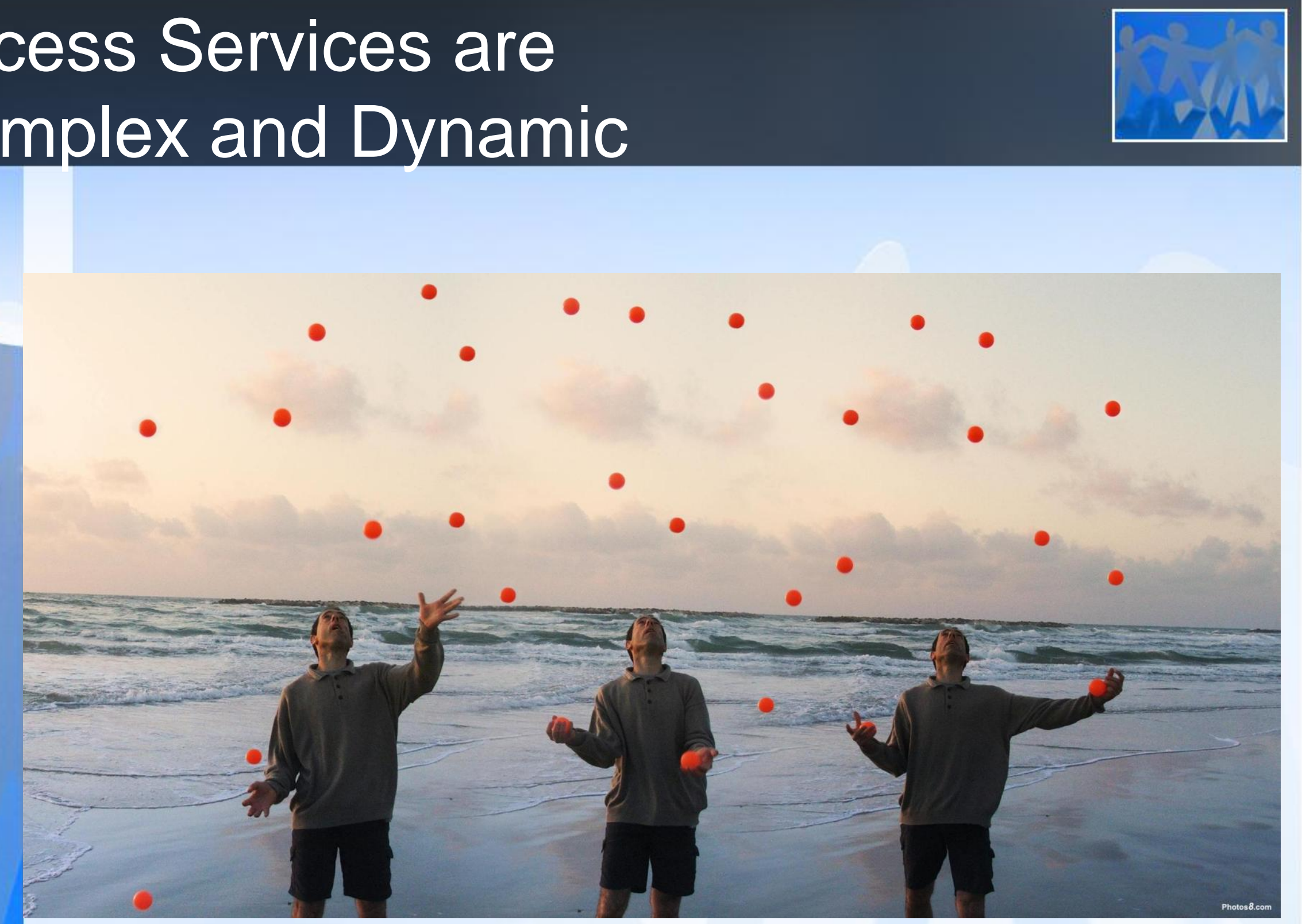

http://www.eeuwigheid.nl/missional-communities/de-voorganger-alsduizendpoot/attachment/by-photos8-com/ 


\section{Access Services Functions}

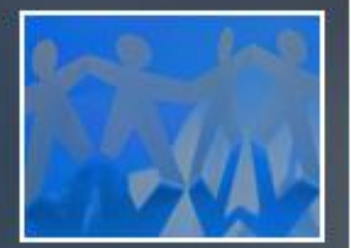

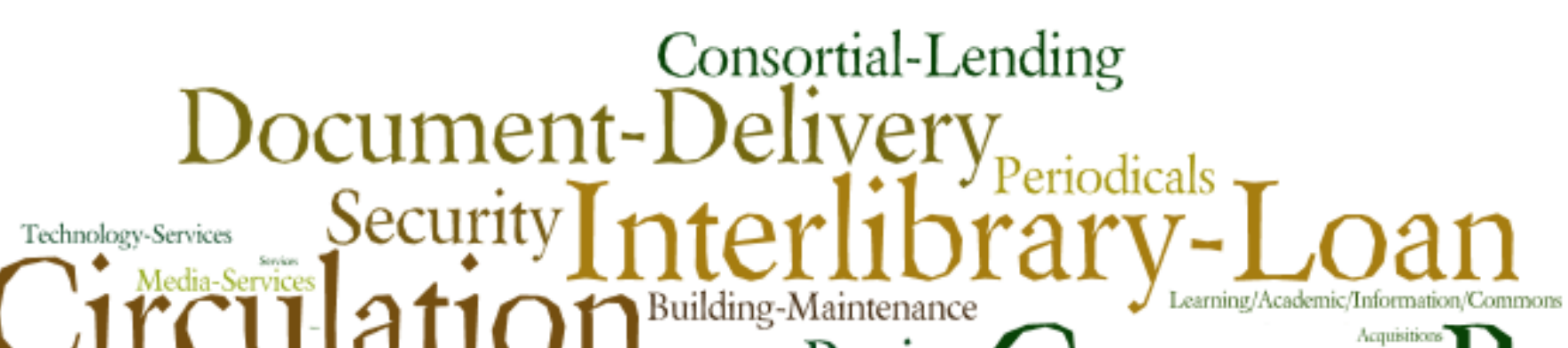

circulation

Paging

Course-Reserves

$$
\begin{aligned}
& \text { Stacks-Maintenance Memberships } \\
& \text { Shelving Fines-and-Fees } \\
& \text { Fcanning-Copying-Services }
\end{aligned}
$$




\section{Changes has your department experienced over the last five years}

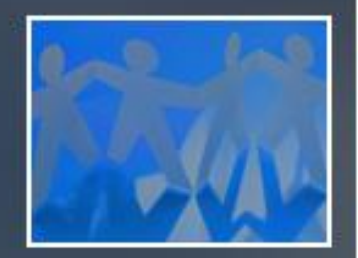

Decreasing staff positions
Increasing cross-training Circulating Electronic Equipment Increasing hours

Renovatinglibrary or new library building Purchasing through Interlibrary Loan E-Reserves services Chat Service Streaming Media Combining ILL and Circulation Textbooks on Reserve Combining Reference and Circulation Providing self-service options Adding new service points Increasing staff positions Combining Interlibrary loan with Acquisitions

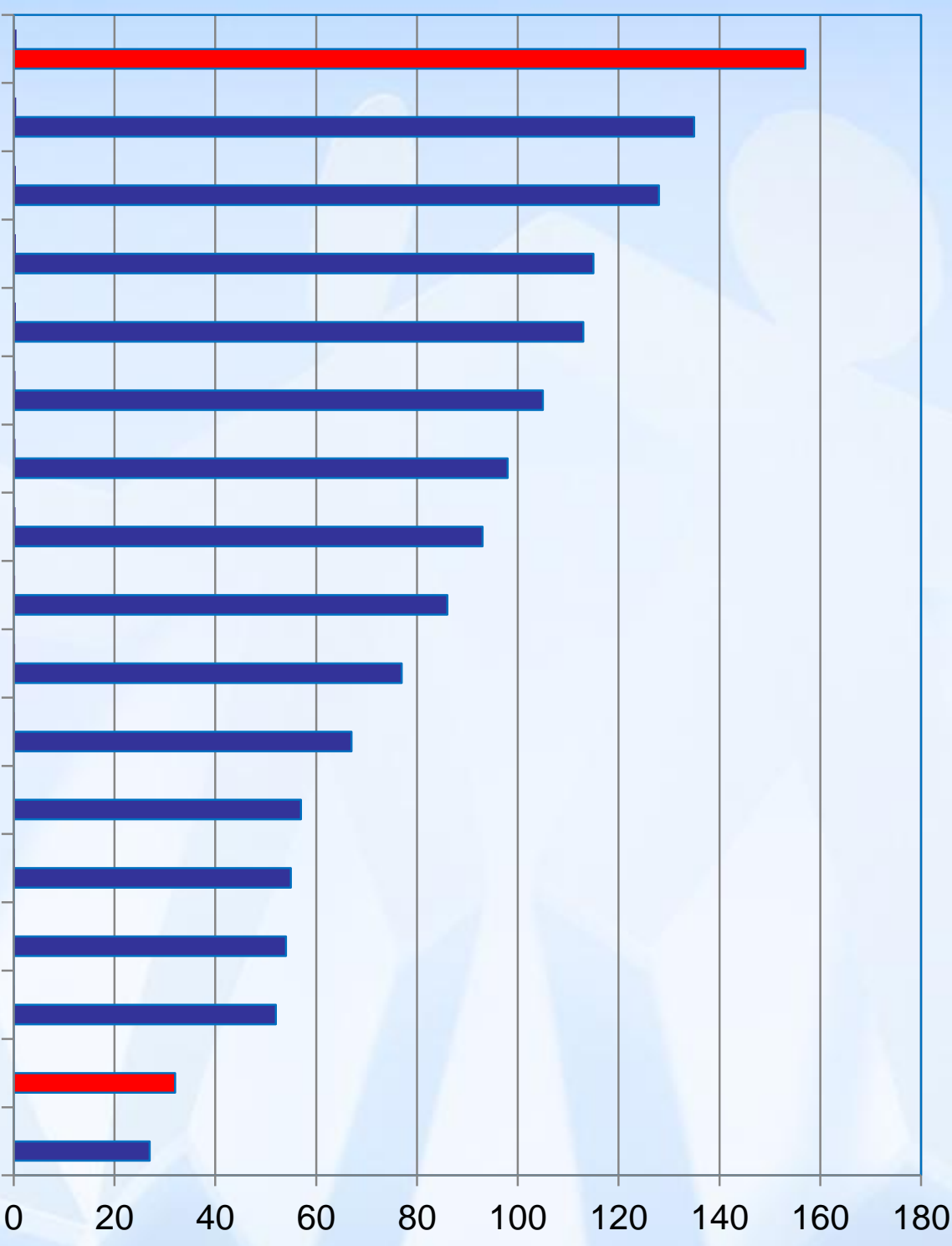




\section{Satisfaction Measures Surveyed}

- Benefits

- Relationships

- Challenges

- Opportunities

Ss tó

- Self-Fulfillment 


\section{Abraham Maslow}

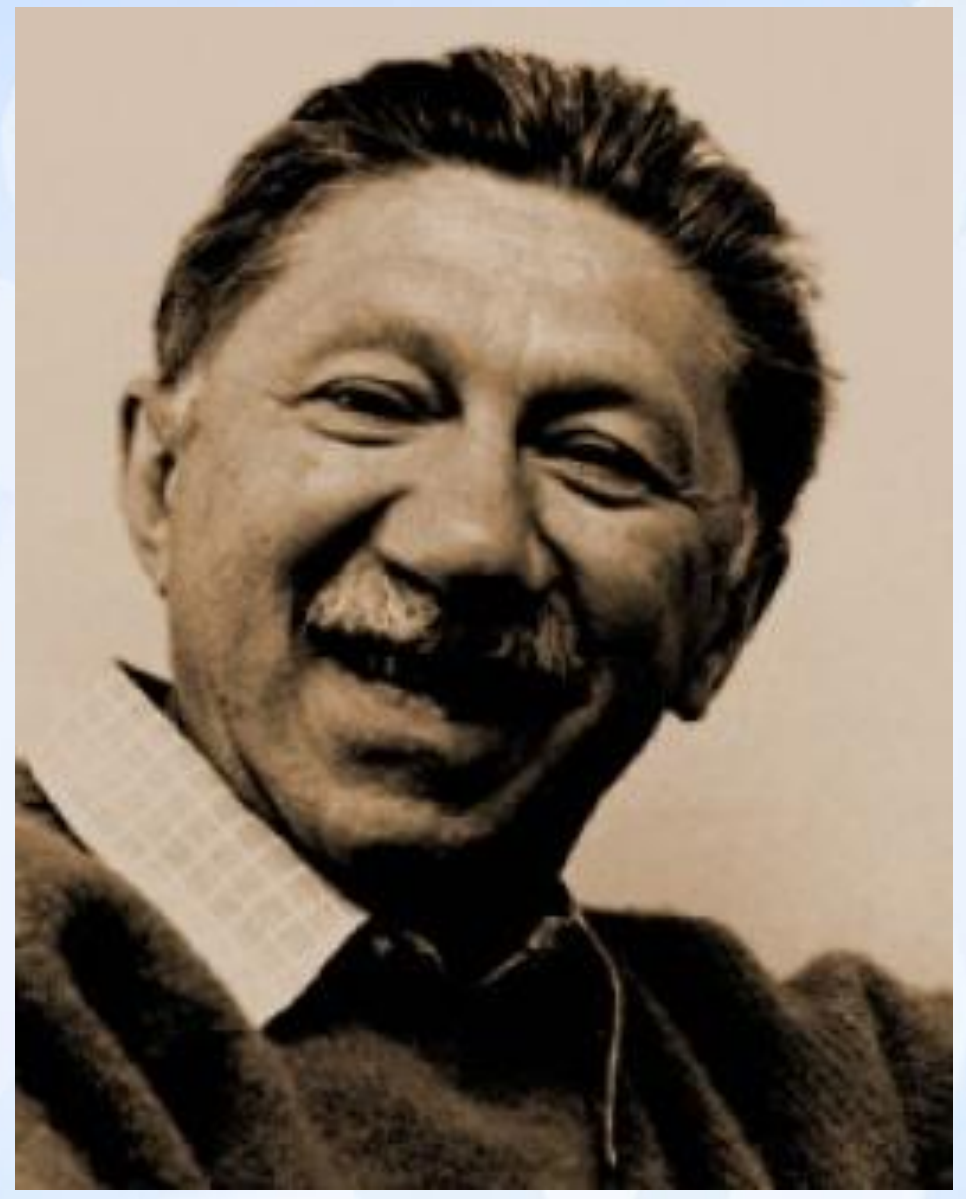




\section{Mazlow's Hierarchy of Needs}

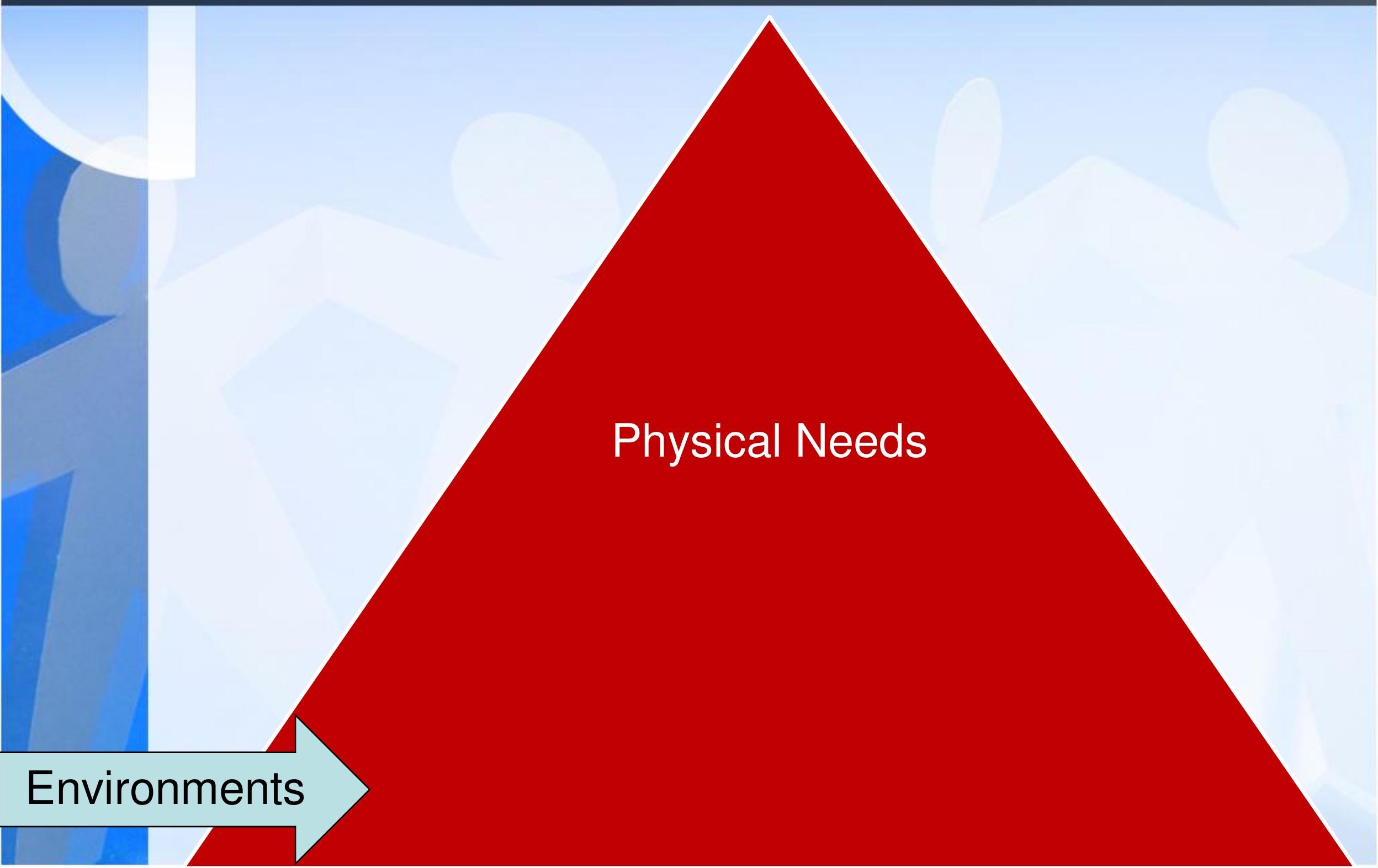




\section{Environments}

* Job Security

* Physical Working

Environment

*Working Hours

*Work Load

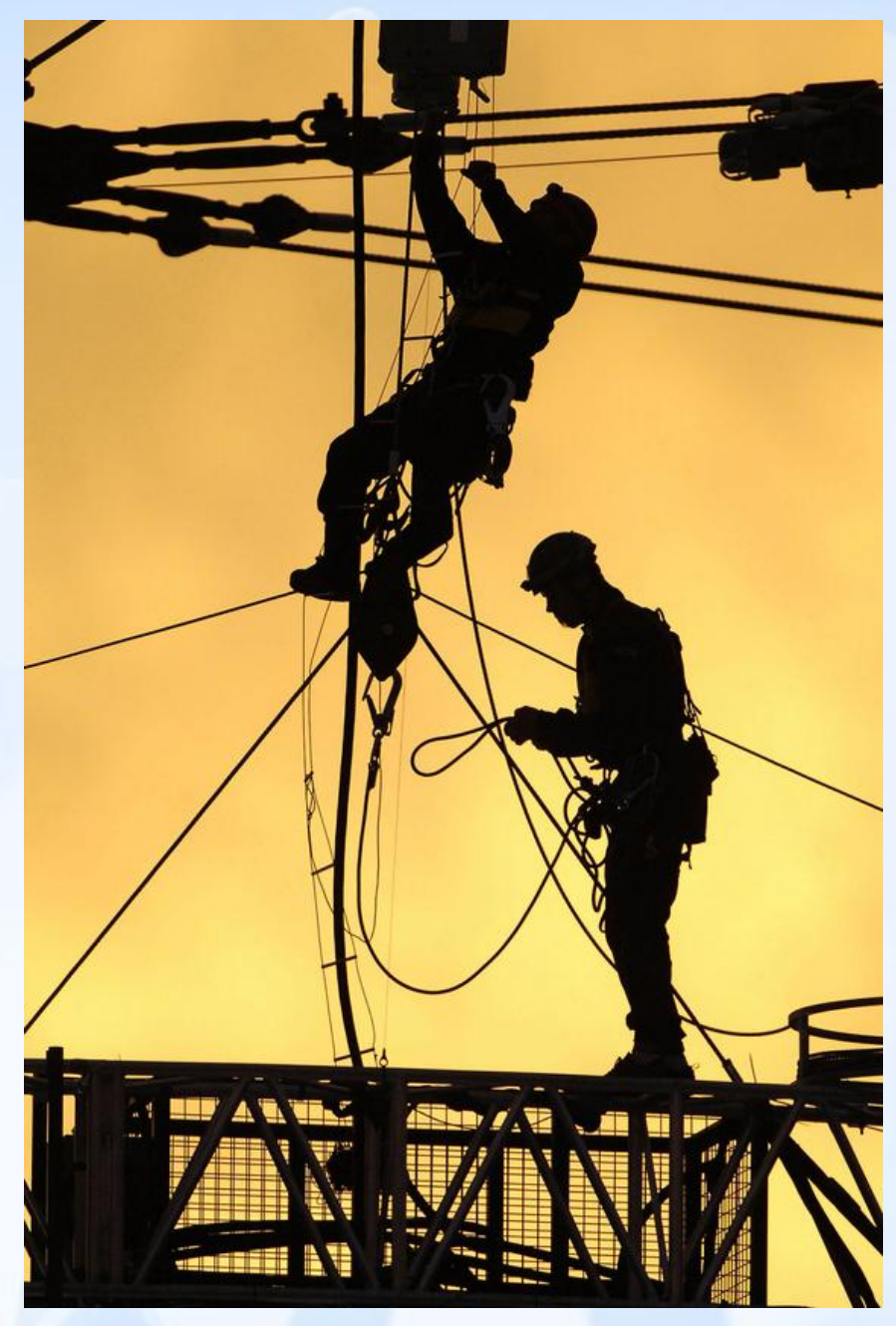




\section{Mazlow's Hierarchy of Needs}

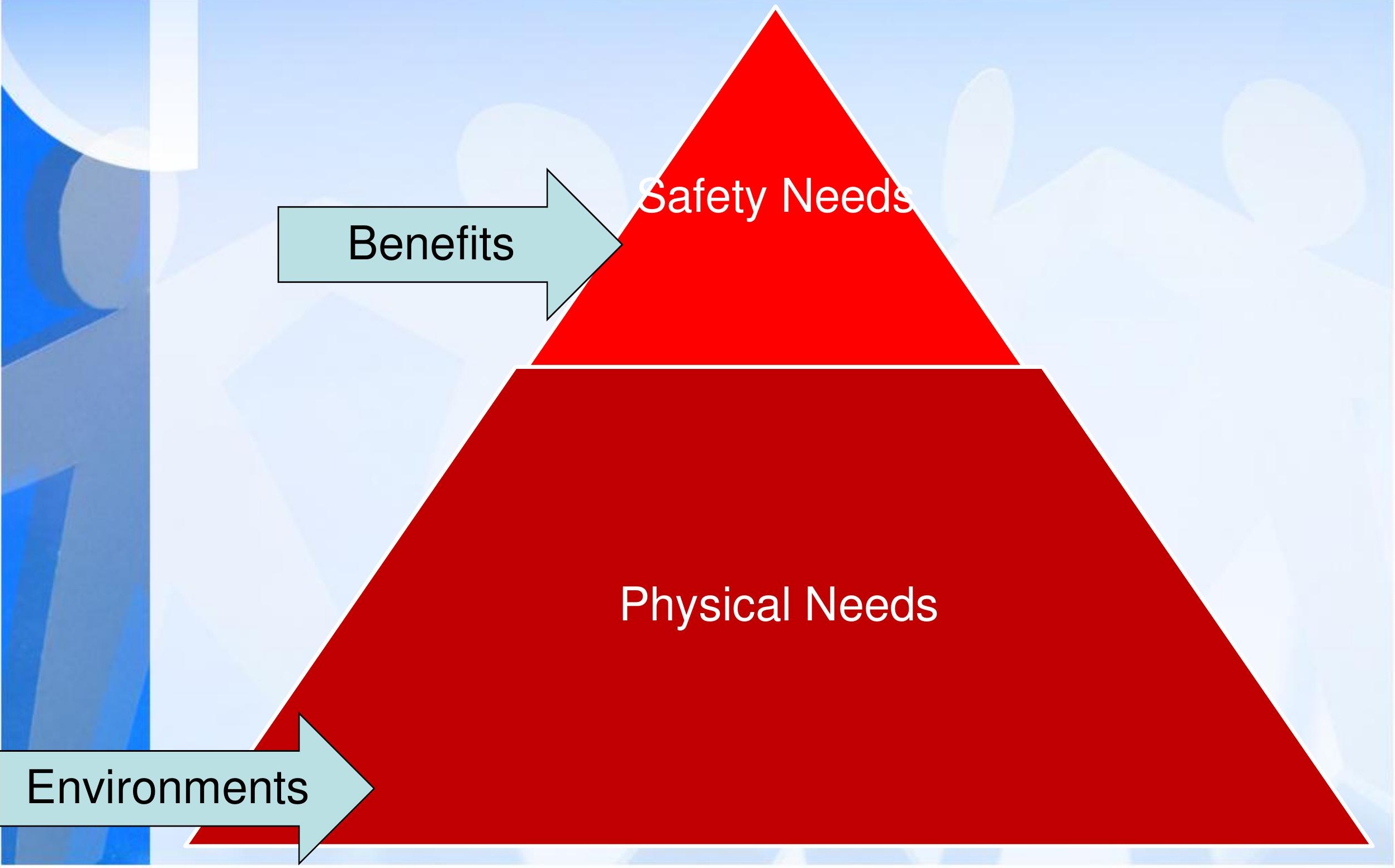




\section{Benefits}

* Salary

* Healthcare Benefits

* Raises

* Union Representation

* Retirement Options

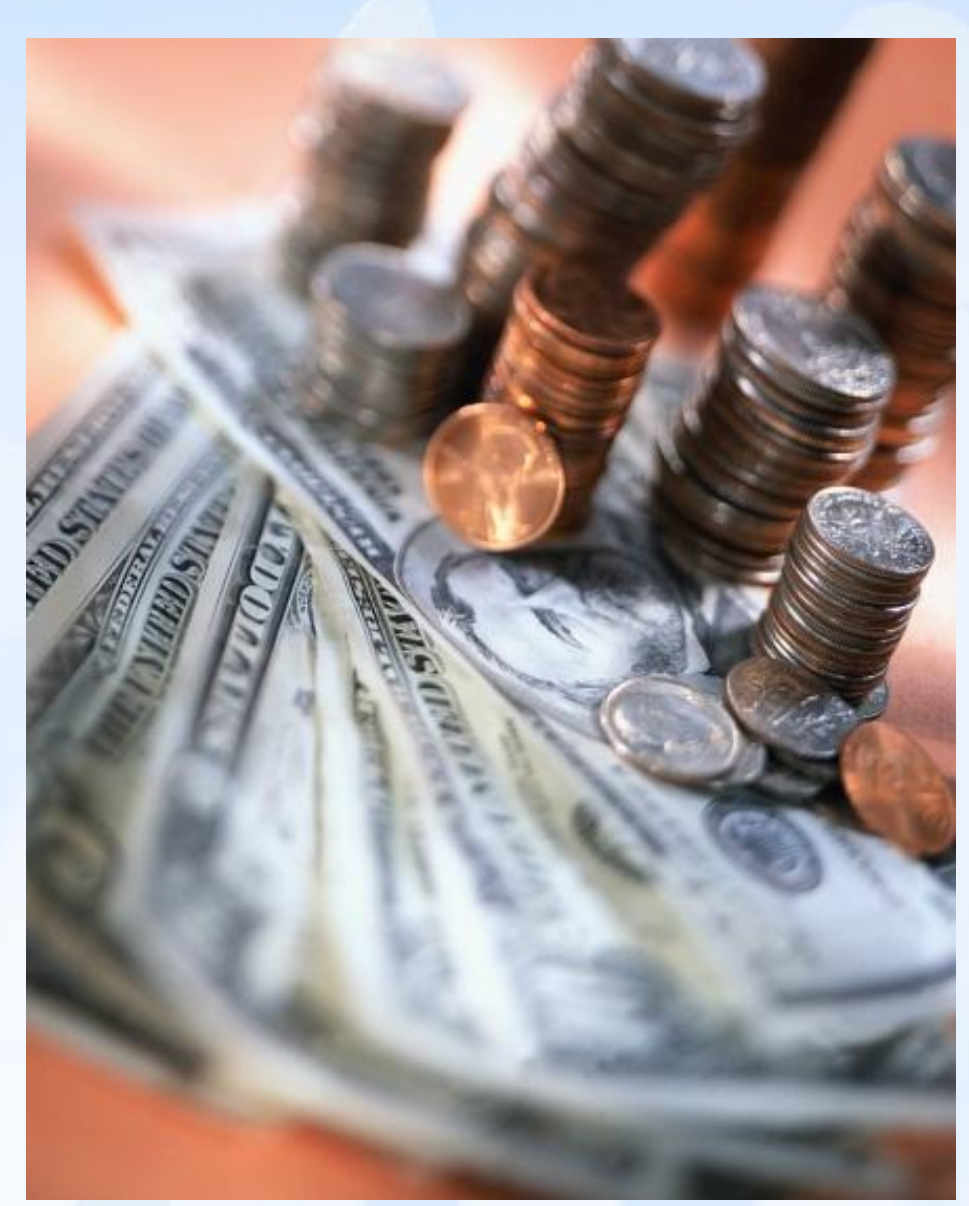




\section{Relationships}

* Relationship with Peers

* Relationship with Library Users

* Relationship with Supervisor

* Understanding the Library's Mission

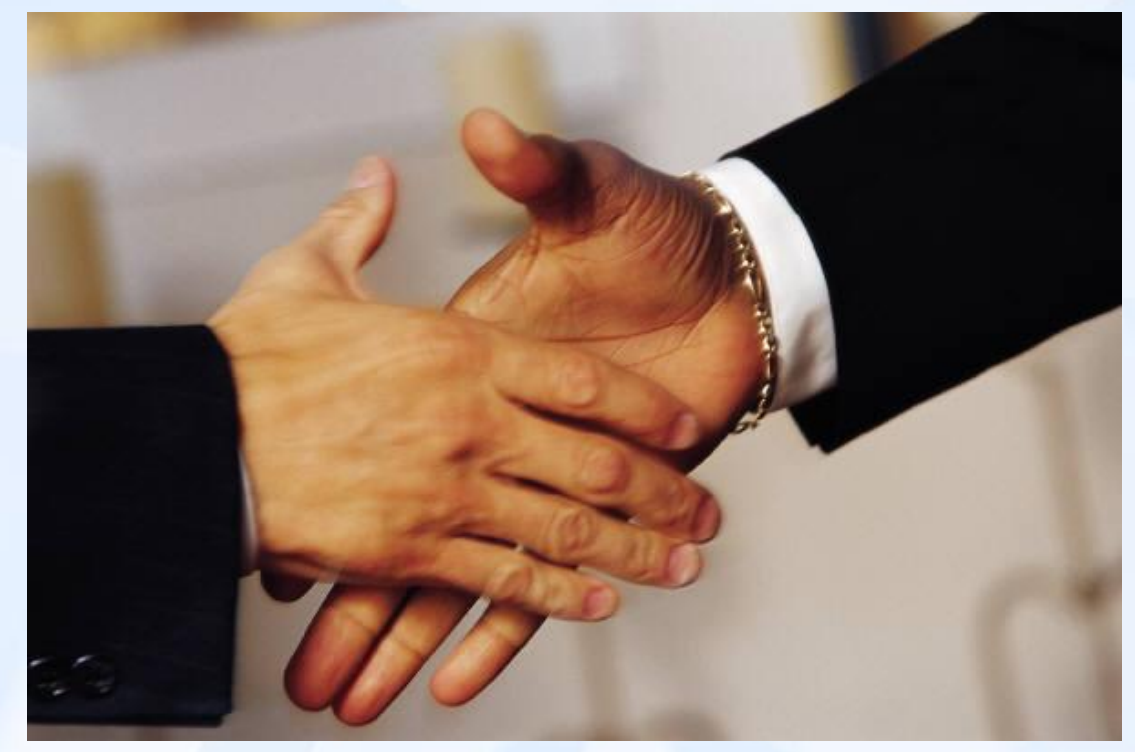




\section{Mazlow's Hierarchy of Needs}

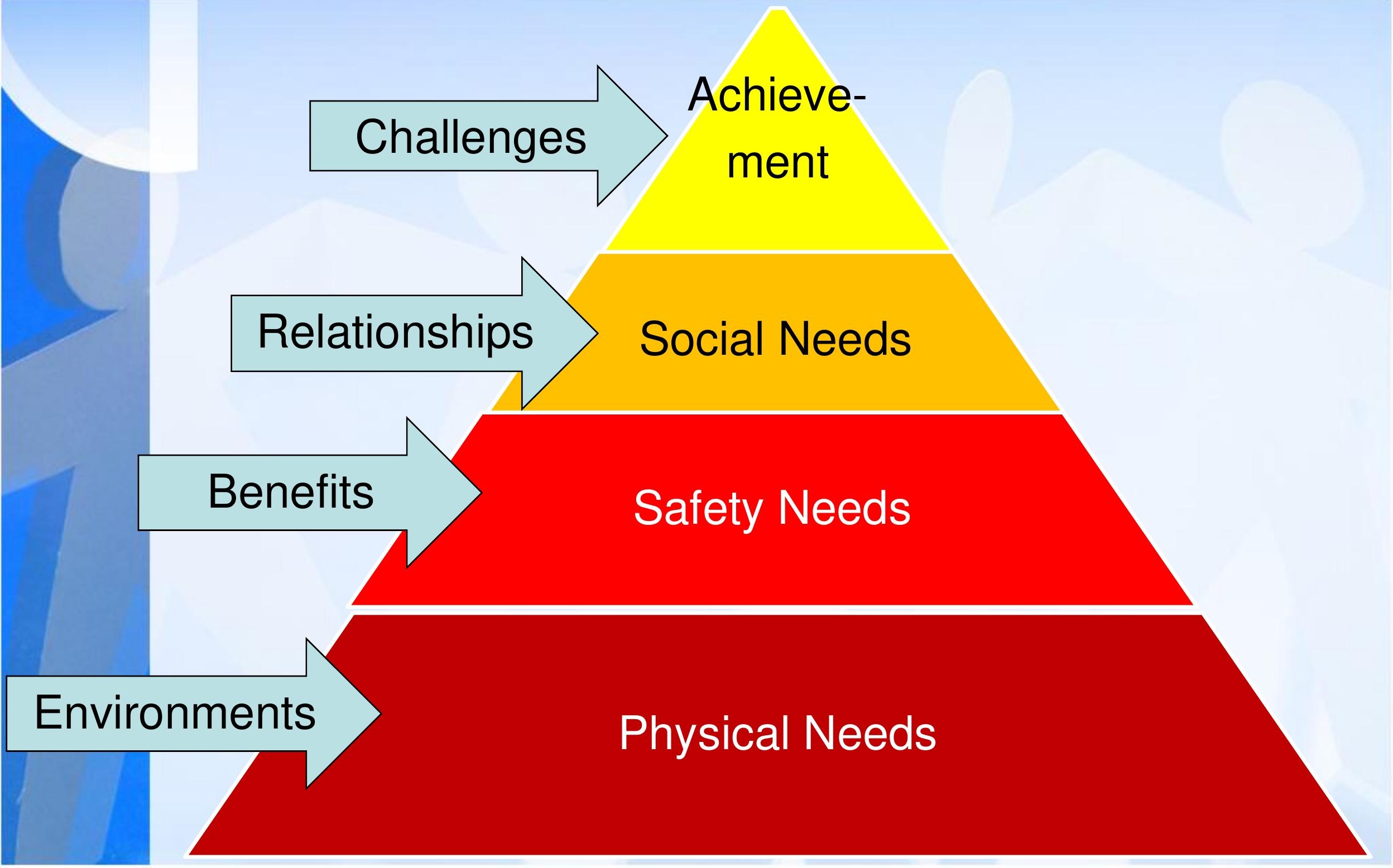




\section{Challenges}

* Use of Skills

* Degree of

Autonomy and Independence

* Level of Difficulty of Tasks

$*$ Variety of Tasks * Resources to do hitp///michaelpeteless.org/the-poi-

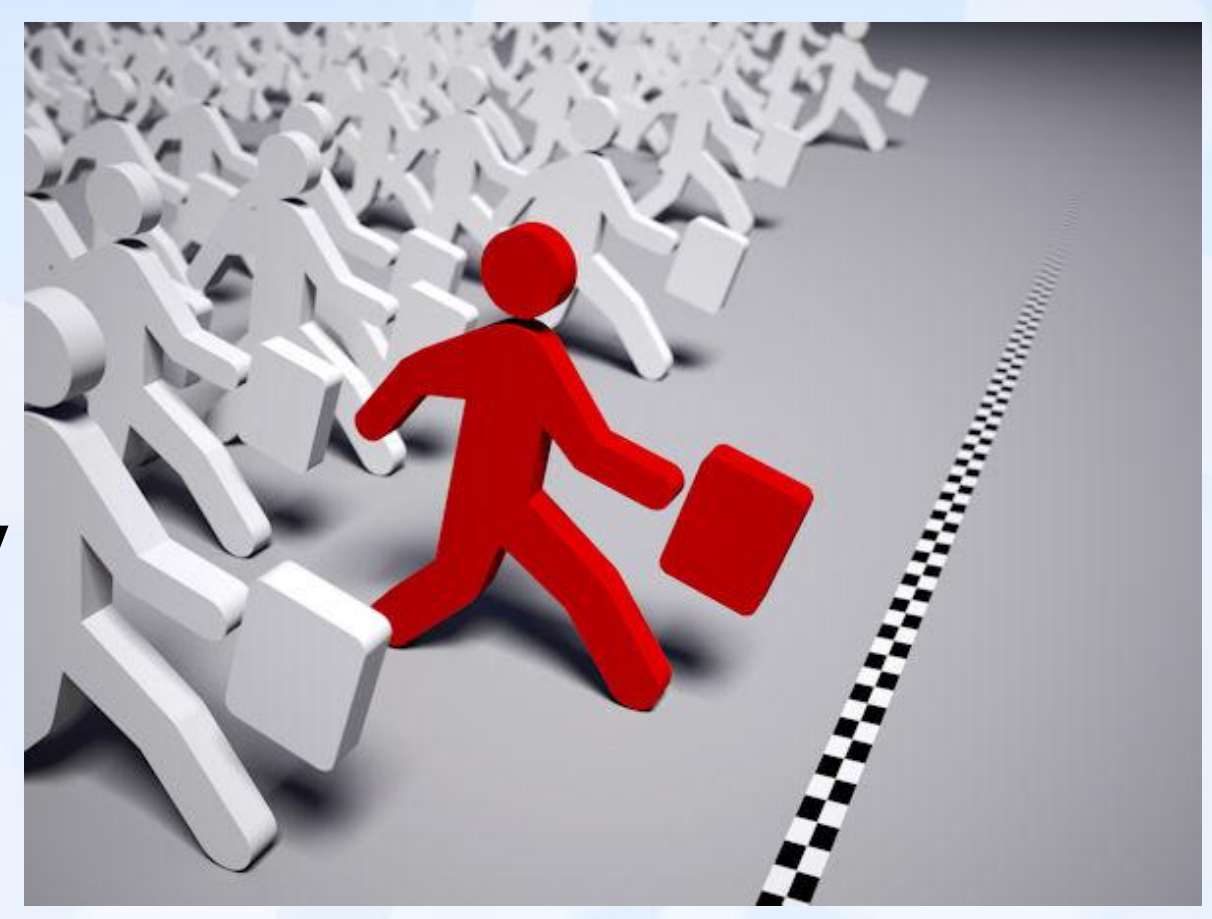

Your Job 


\section{Mazlow's Hierarchy of Needs}

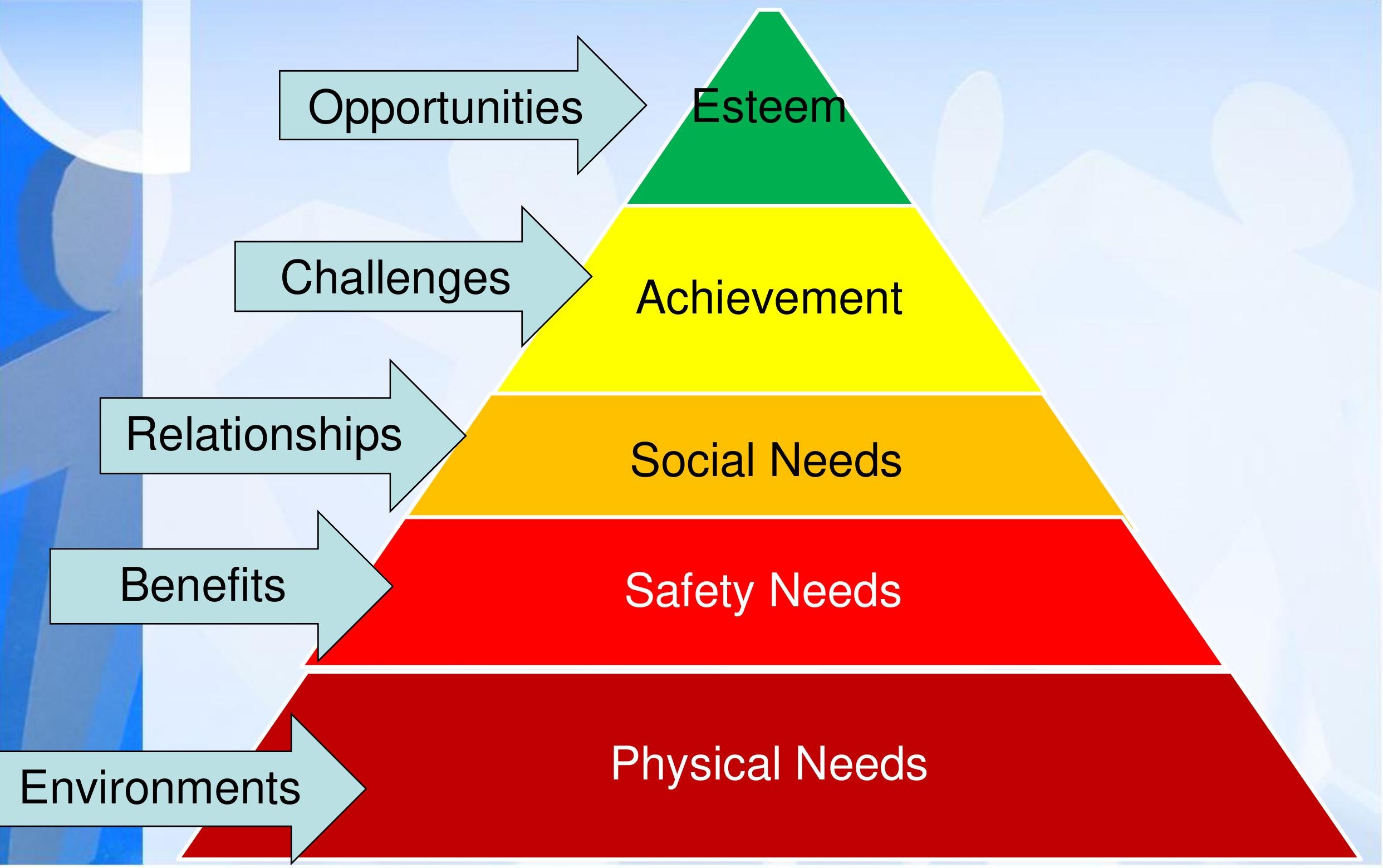




\section{Mazlow's Hierarchy of Needs}

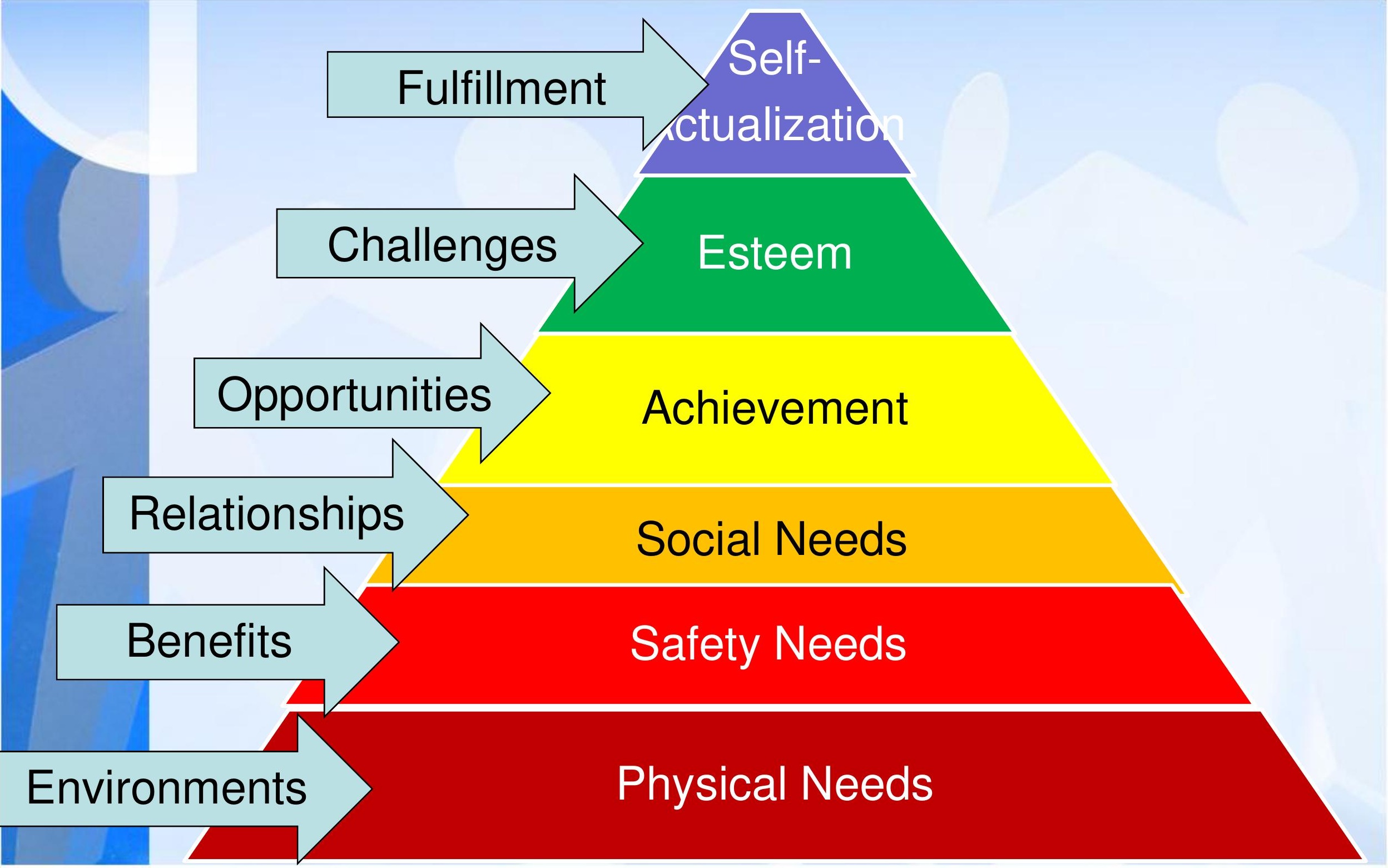




\section{Personal Fulfillment}

* Impact on the Community

* Sense of

Achievement

* Enjoyment in Doing Your Job

* Level of Prestige

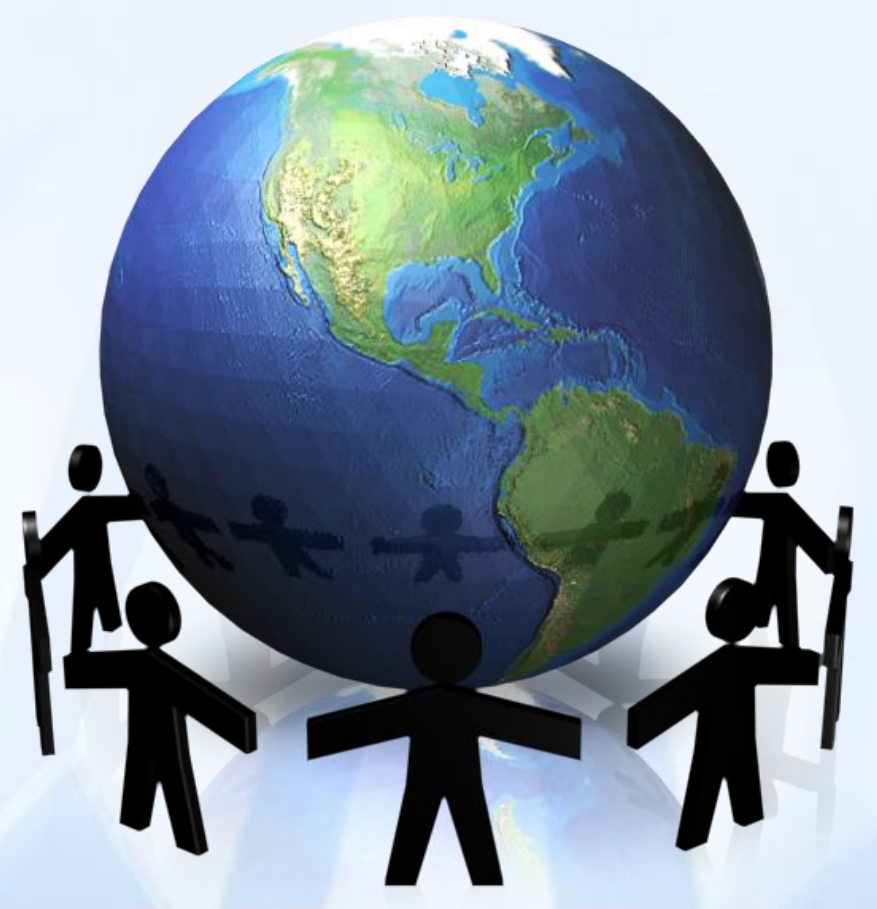




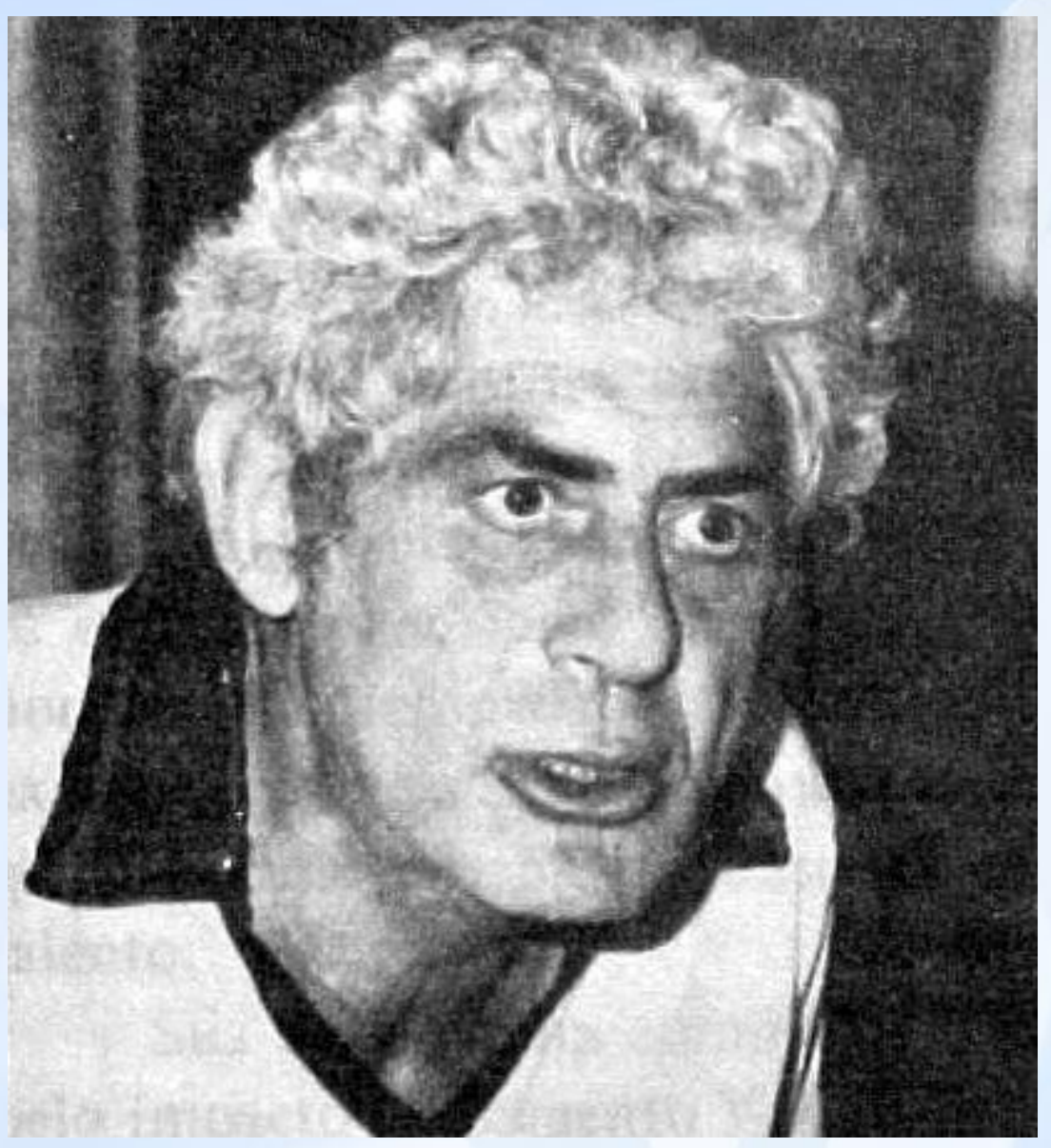




\section{Herzberg's Two-Factor Theory}

\section{Hygiene Factors}

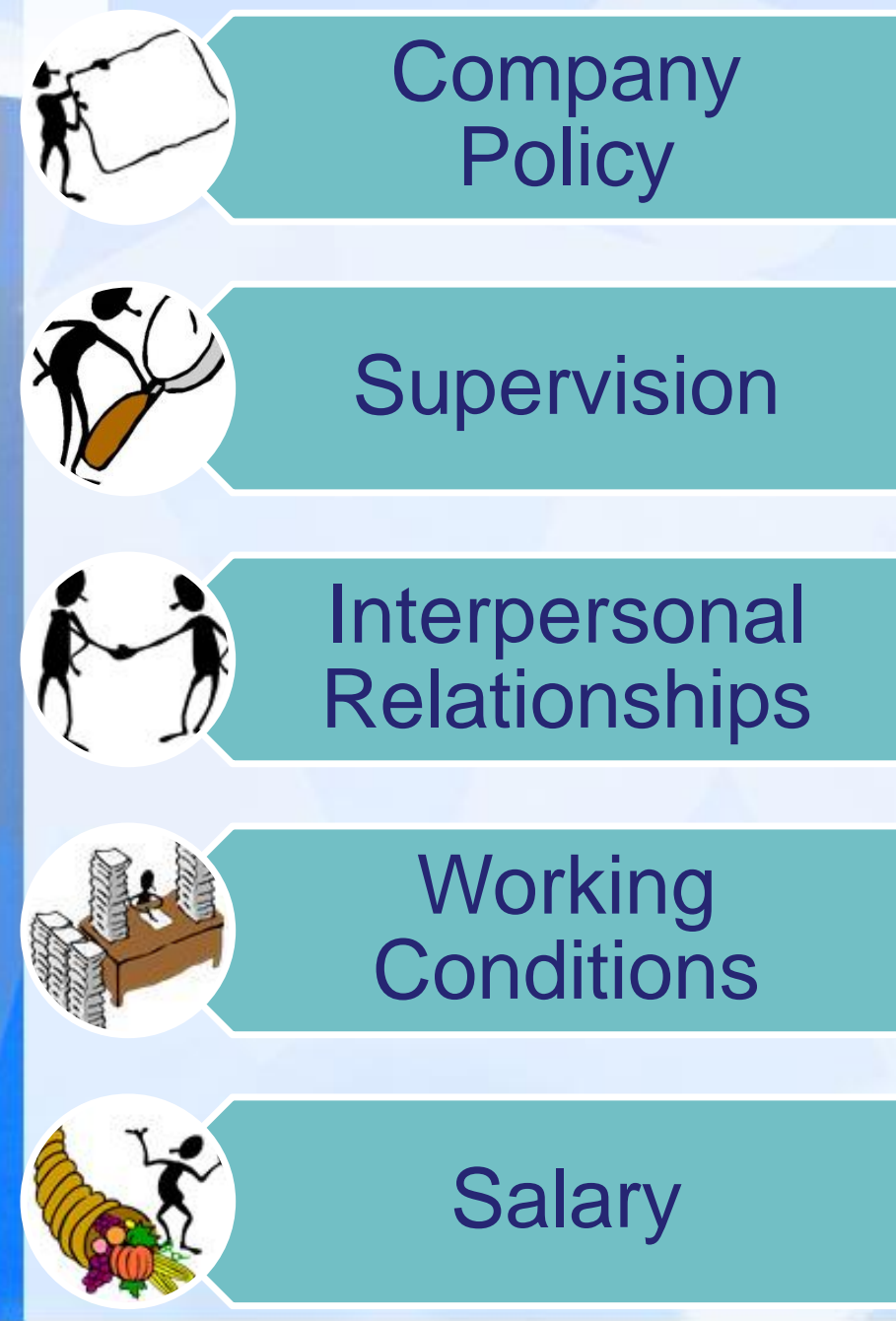

\section{Motivators}

约 Achievement

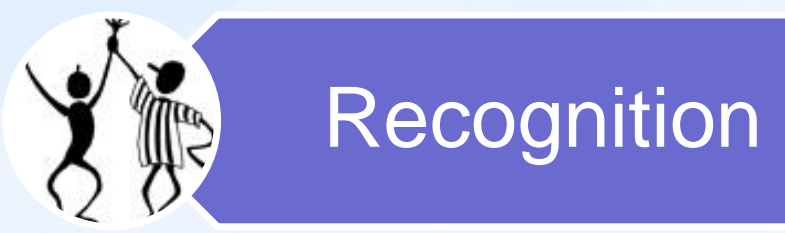

年 The Work Itself

Responsibility

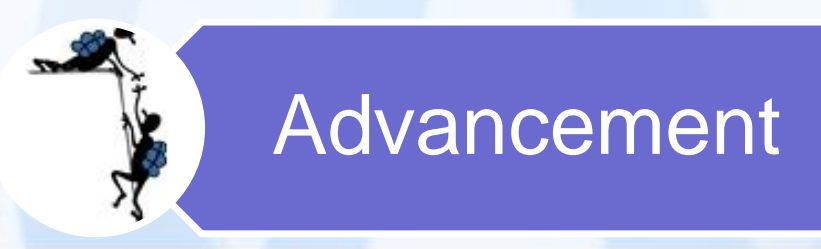




\section{Mazlow's Hierarchy of Needs}

The work itself

\section{}

Seli-

ctualizatio

Recognition

Esteem

$\wedge$

Achievement Achievement

\section{Relationships}

Salary
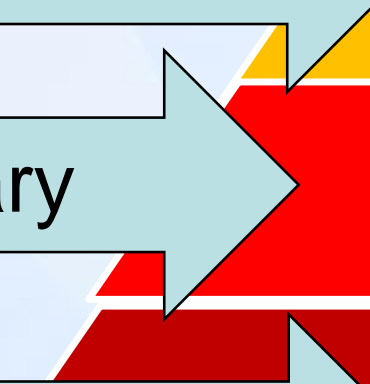

Working Conditions

\section{Social Needs}

Safety Needs

Physical Needs 


\section{Important Factors for Job Satisfaction}

Personal Fulfillment

Relationships

Opportunities

Challenges

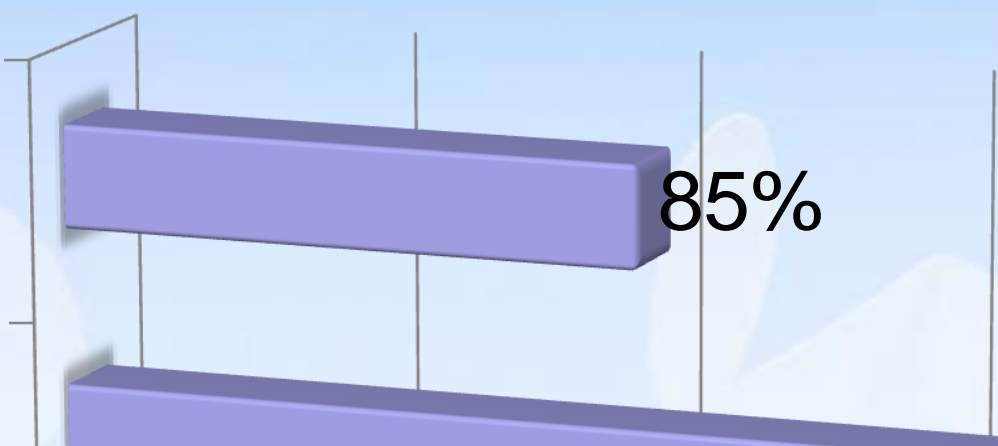

Benefits

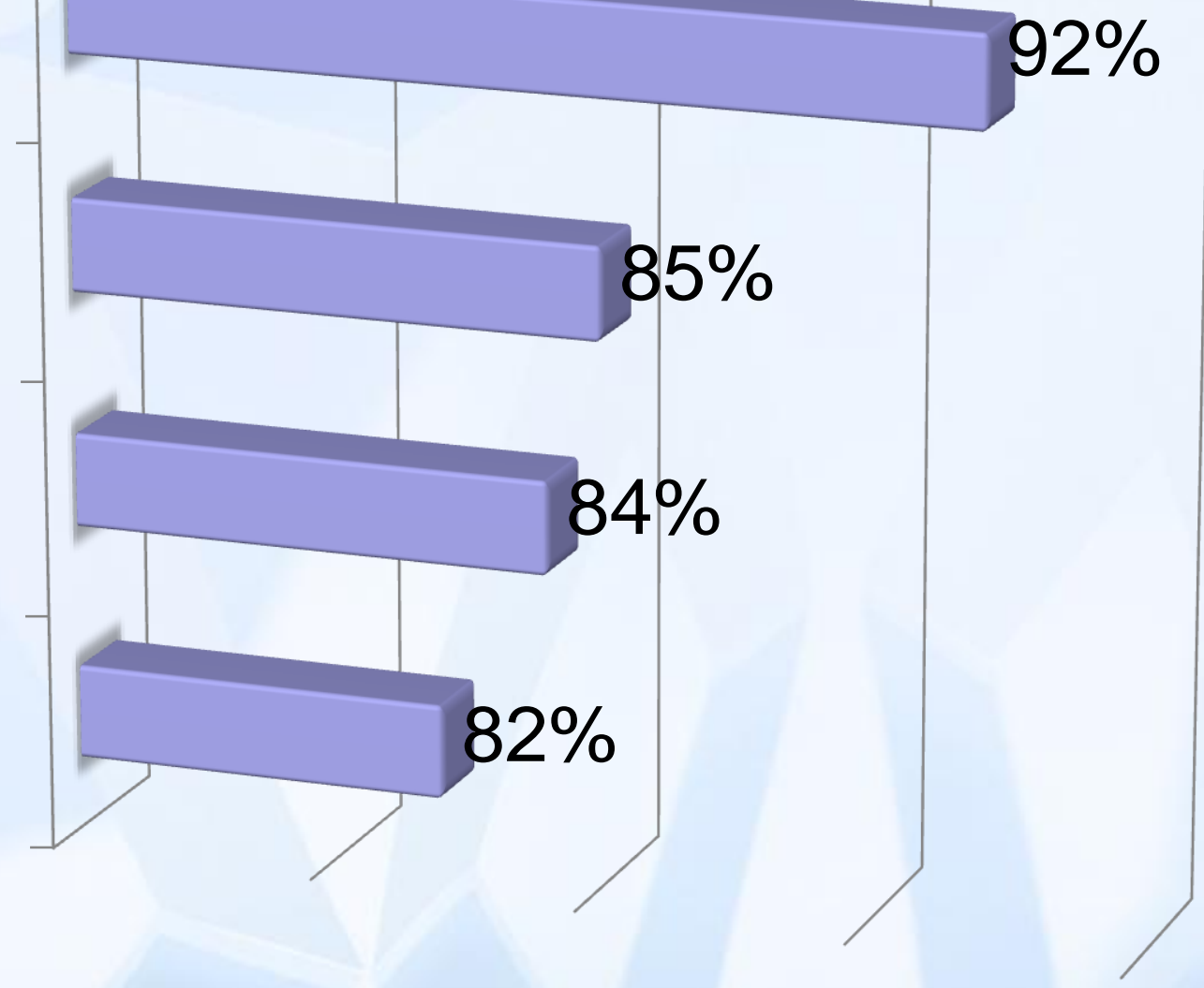




\section{Actual Satisfaction by Job Factors}

Relationships

Personal Fulfillment

Opportunities

Challenges

Benefits

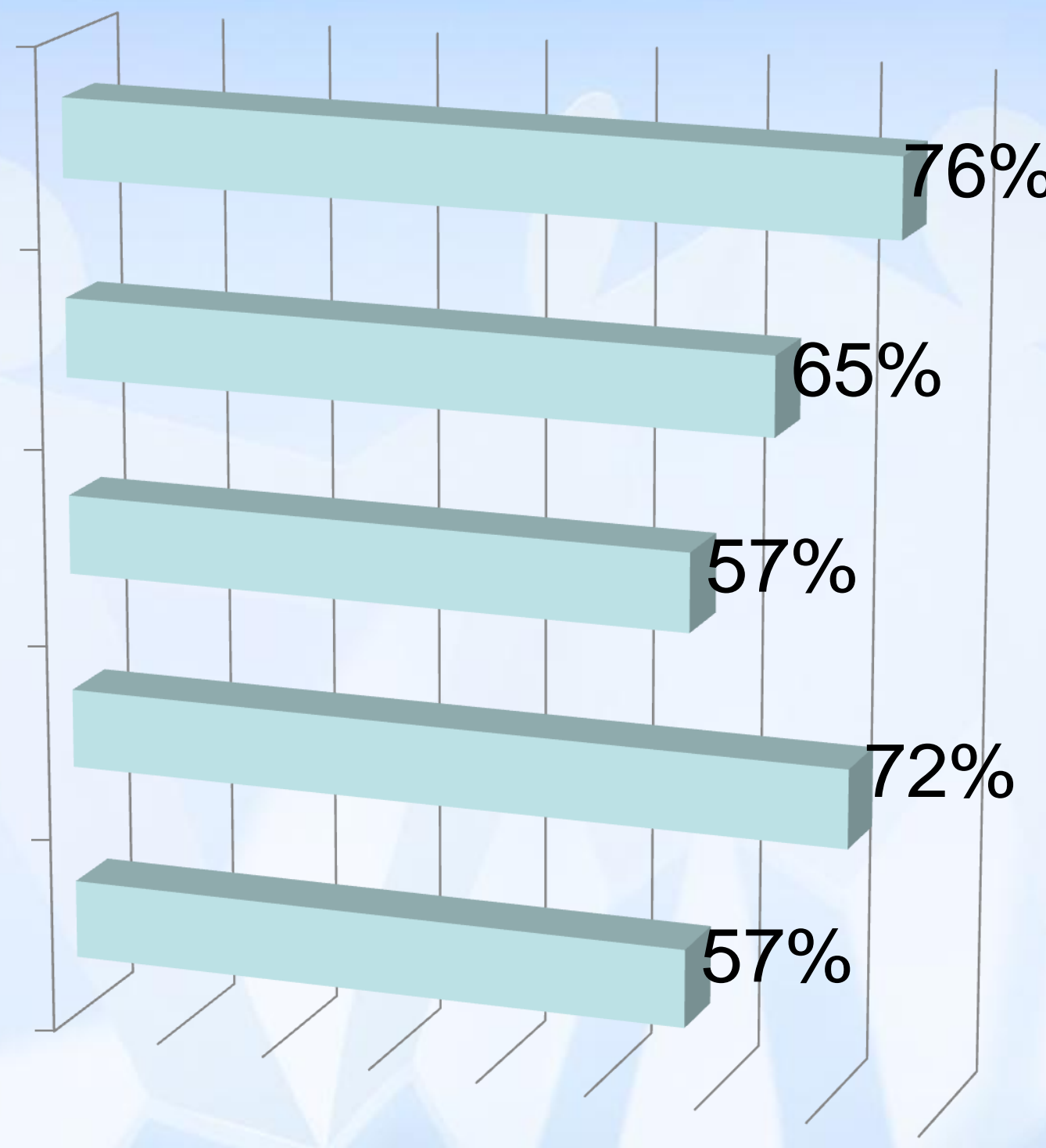




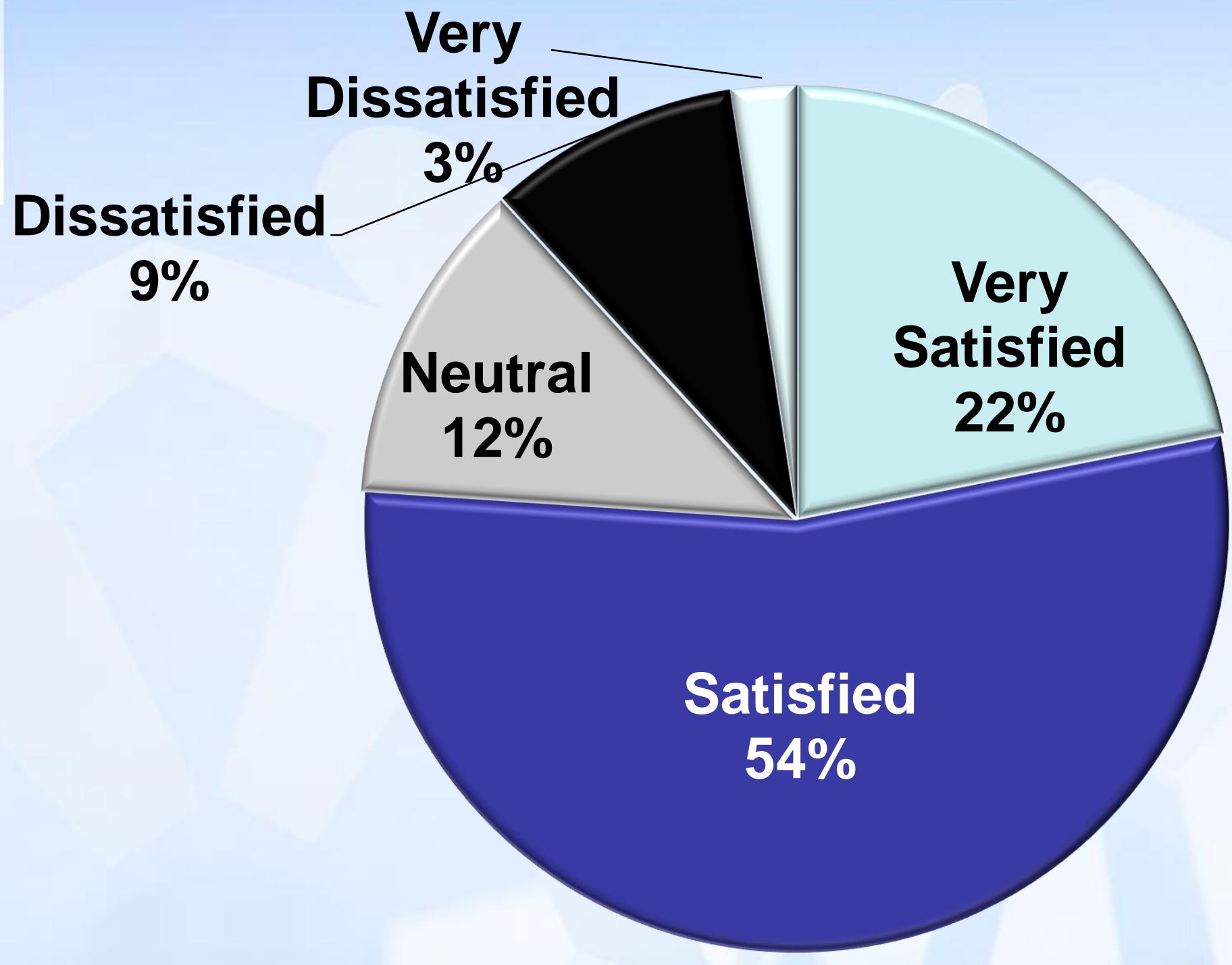




\section{All Satisfaction Categories Combined}

Very

Dissatisfied

Dissatisfied

$10 \%$

$14 \%$

Neutral

$18 \%$

\section{Very}

Satisfied

$20 \%$

Satisfied

$38 \%$ 


\section{Most Satisfied and Dissatisfied Factors}

\section{Top 5 - Satisfaction}

1. Relationship with Library Users

2. JOB SECURITY

3. Autonomy and Independence

4. Work

Environment

5. Understanding Library's Mission

\section{Bottom 5 - Dissatisfaction}

5. Workload

4. Salary

3. Influence Decisions

2. Advancement

1. Raises 


\section{Satisfaction Based on Age}

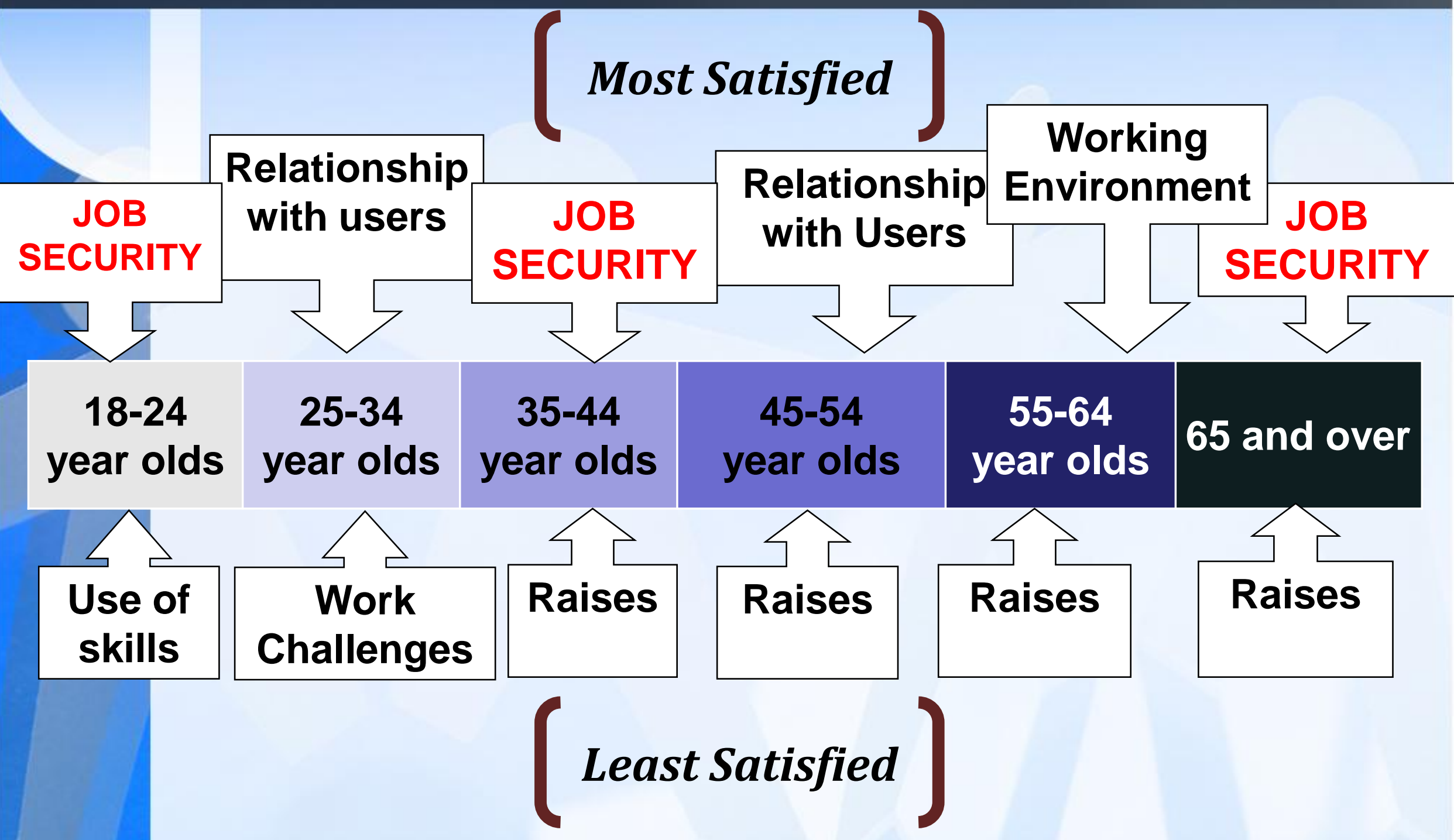




\section{Satisfaction Based on Education}

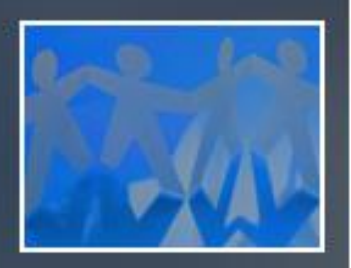

\section{High School}

\section{Top 5 Satisfied}

- Resources

Provided to do Job

- JOB SECURITY

- Variety of tasks

- Degree of autonomy \& independence

- Institution training \& seminars

\section{College Degree}

\section{Top 5 Satisfied}

1. Working environment

2. Recognition from library users

3. Understanding library mission

4. Degree of autonomy \& independence 5. JOB SECURITY
Master's or Phd

Top 5 Satisfied

1. Library users

2. JOB SECURITY

3. Recognition from library users

4. Understanding library mission

5. Degree of autonomy \& independence 


\section{Satisfaction of Supervisors}

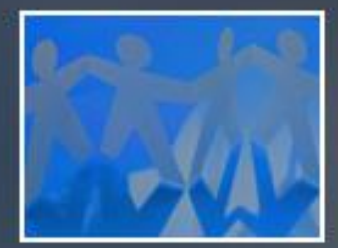

\section{Top 5 -Satisfaction}

\section{JOB SECURITY}

2. Variety of Tasks

3. Autonomy and Independence

4. Library Users

5. Understanding Library Mission

\section{Bottom 5 - Dissatisfaction}

5. Salary

4. Workload

3. Raises

2. Opportunity for Advancement

1. Influence Decisions 


\section{Most Interesting Library Jobs}

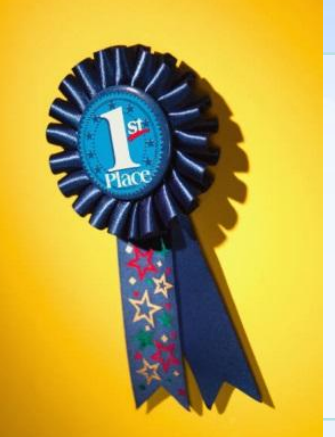

Access Services! (Or some variant thereof)

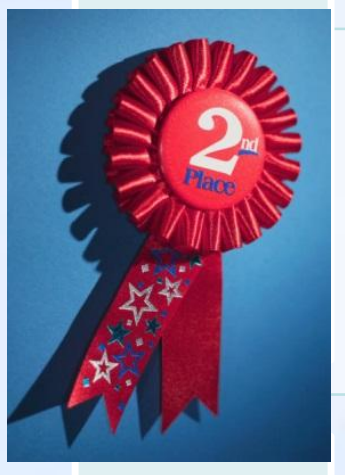

Current Position

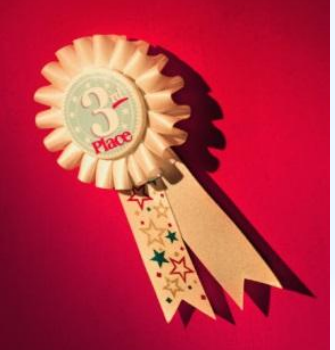

Any position working with the public 


\section{Research Shows}

- "CO [Customer Orientation] is associated with higher levels of job satisfaction, commitment, and OCBs [Organizational citizenship behaviors]."*

- Translation "Customer Service workers are satisfied with their work"

Bethany B. Sewell

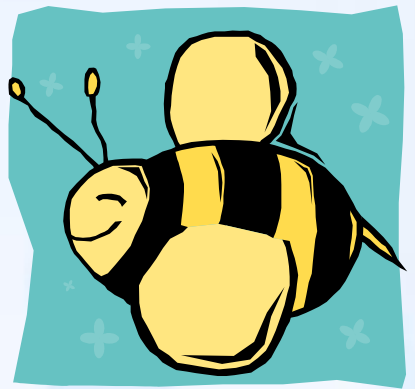

*Donavan D, Brown T, Mowen J. Internal Benefits of Service-Worker Customer Orientation: Job Satisfaction, Commitment, and Organizational Citizenship Behaviors. Journal Of Marketing [serial online]. January 2004;68(1):128-146. Available from: Communication \& Mass Media Complete, Ipswich, MA. Accessed September 29, 2013. 


\section{Areas for Improvements}

Training

Workload

Opportunities

Promonlons

\section{Recoginition}

Supportive

Administration

\section{Communication}

Keeping Up with Trends

\section{COMBINED} SERVICE DESK 


\section{Lessons Learned}

- Shorten the survey

- Salary range of the respondent

- Percentage of autonomy in current position

- $\quad$ Ask more 'why' questions

- Specific rank of the position the respondent was holding

"We would like the professionals to treat the staff with more respect, since most of the staff know their own job better than the professionals, stop micro managing."

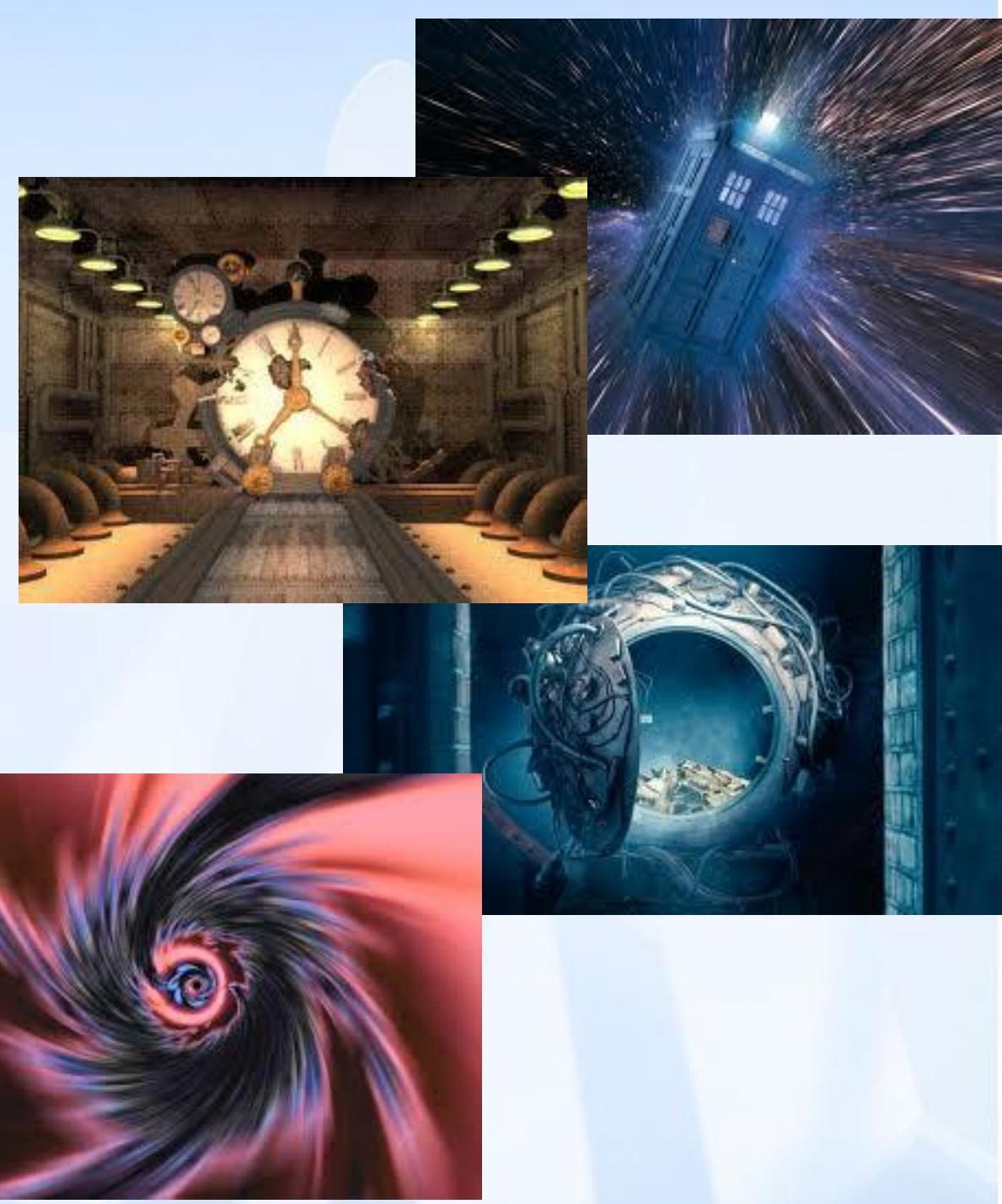




\section{What's Next?}

- Continue to analyze the data

- More research

- Share findings
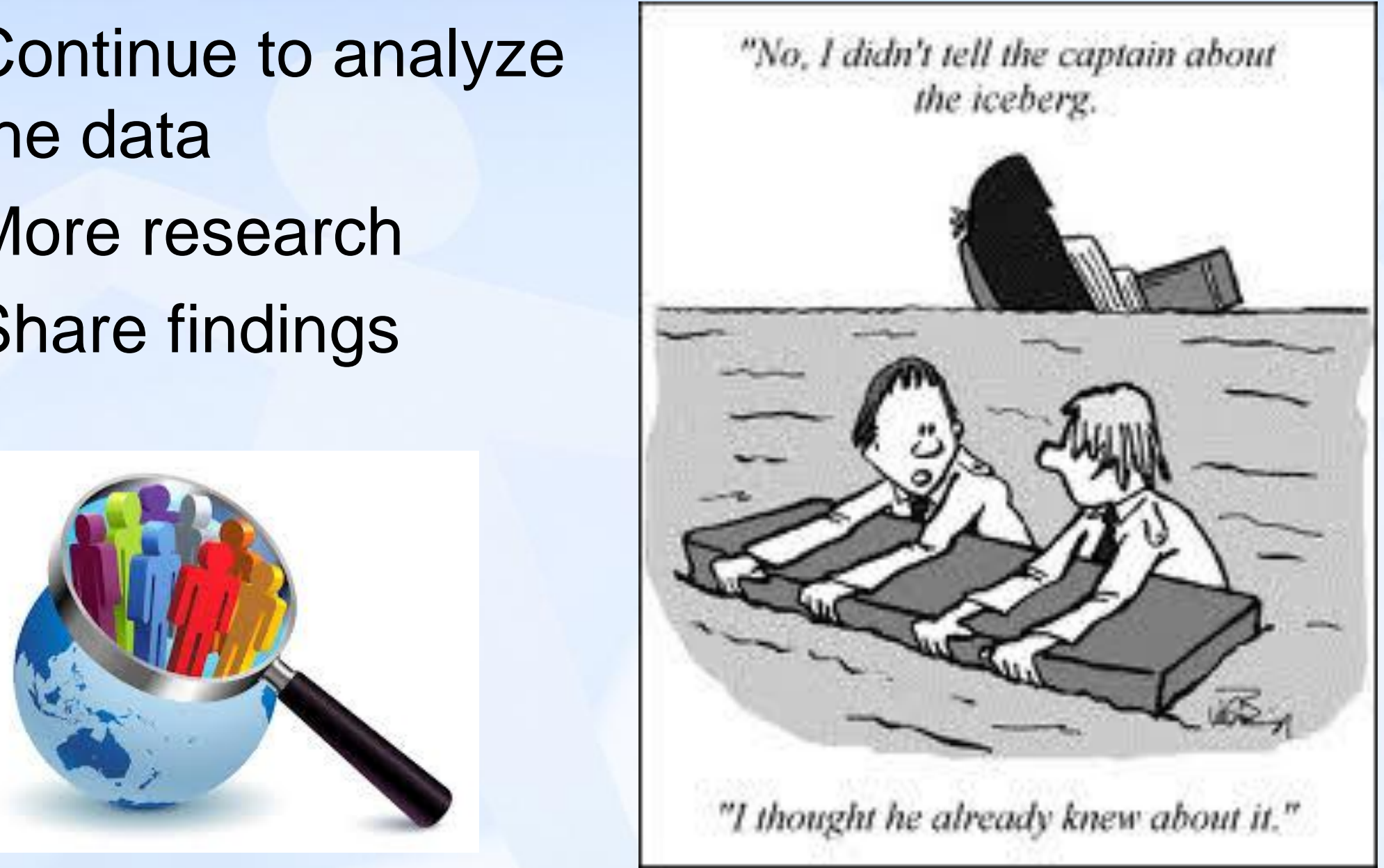


\section{Additional Summarized Comments}

- We love our job

- Even though we are overworked,

- Integrating more services,

- And feel that we do not get enough recognition. 


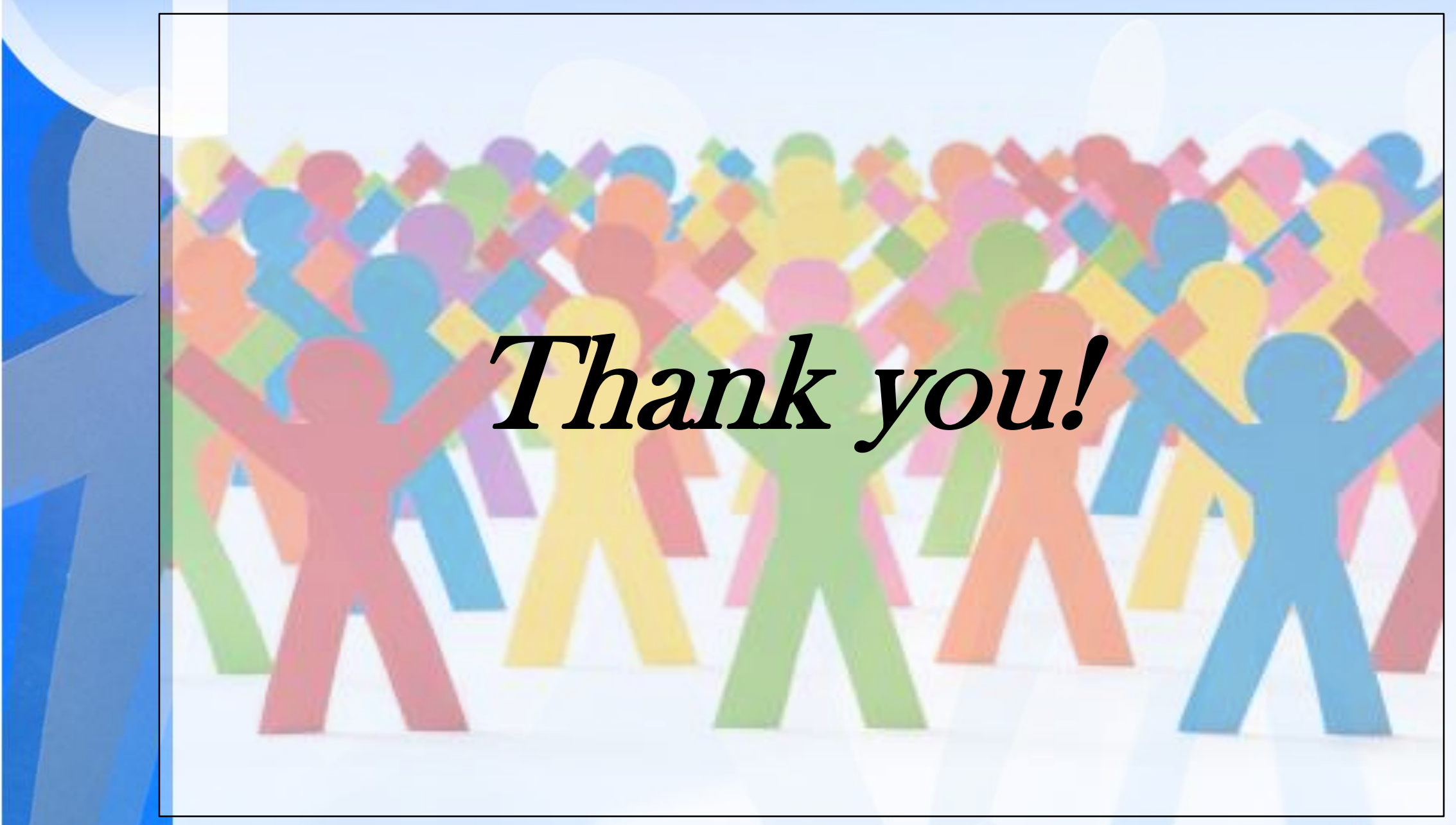


Questions.?

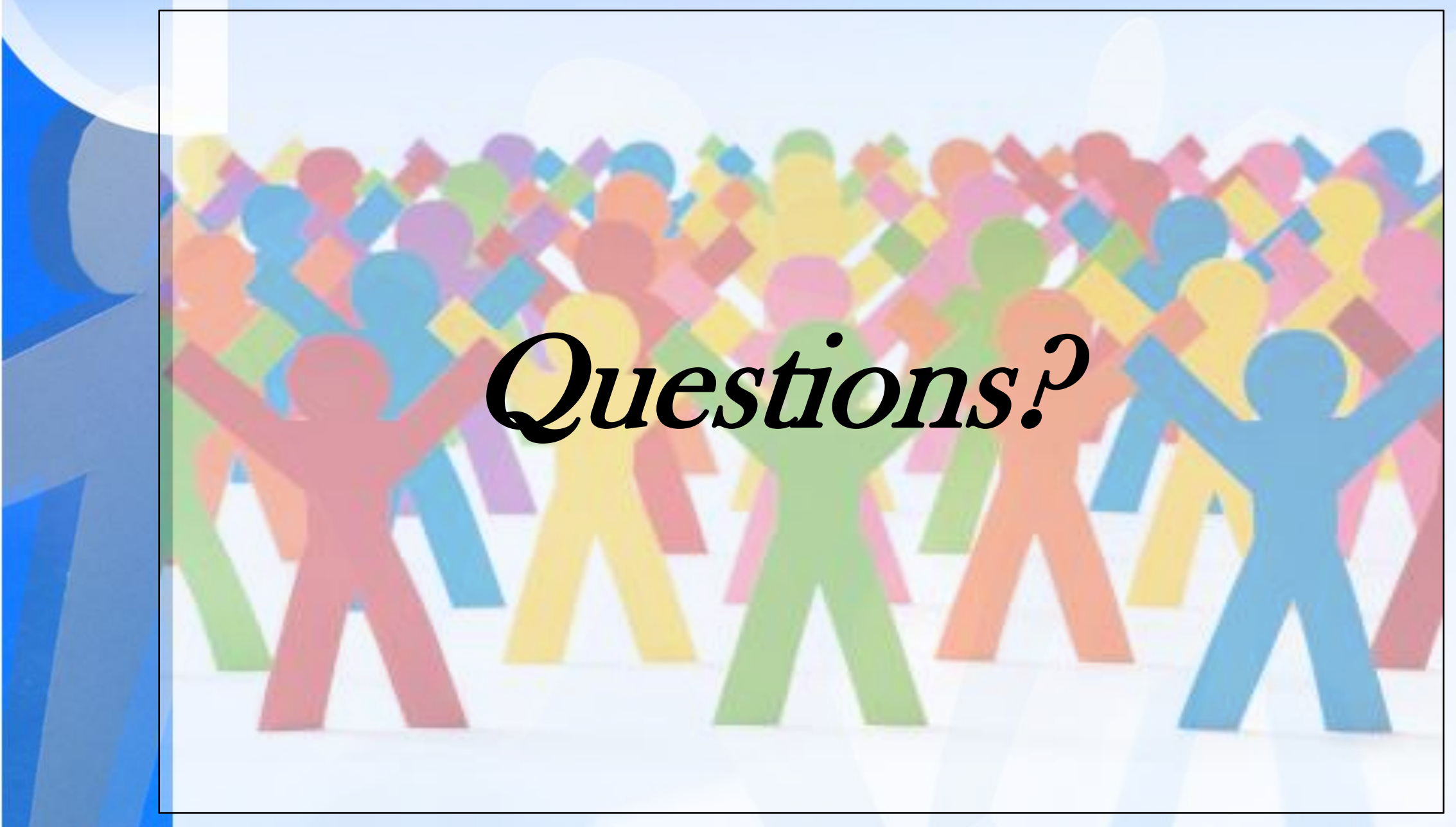

